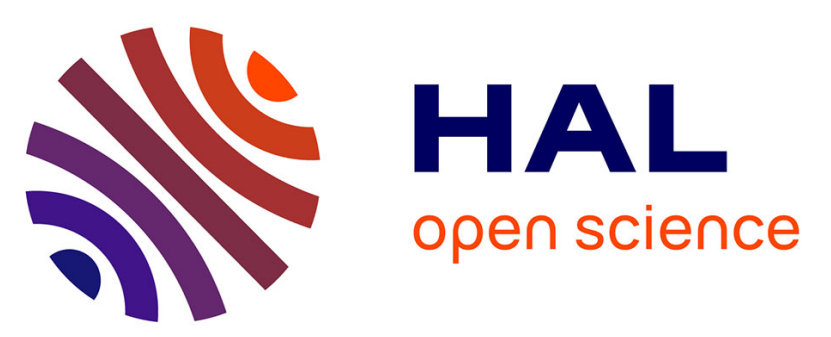

\title{
Semipermeable membrane devices link site-specific contaminants to effects: Part 1 - induction of cyp1a in rainbow trout from contaminants in prince william sound, Alaska
}

Kathrine R. Springman, Jeffrey W. Short, Mandy R. Lindeberg, Jacek M. Maselko, Colin Khan, Peter V. Hodson, Stanley D. Rice

\section{To cite this version:}

Kathrine R. Springman, Jeffrey W. Short, Mandy R. Lindeberg, Jacek M. Maselko, Colin Khan, et al.. Semipermeable membrane devices link site-specific contaminants to effects: Part 1 - induction of cyp1a in rainbow trout from contaminants in prince william sound, Alaska. Marine Environmental Research, 2008, 66 (5), pp.477. 10.1016/j.marenvres.2008.07.001 . hal-00563041

\section{HAL Id: hal-00563041 \\ https://hal.science/hal-00563041}

Submitted on 4 Feb 2011

HAL is a multi-disciplinary open access archive for the deposit and dissemination of scientific research documents, whether they are published or not. The documents may come from teaching and research institutions in France or abroad, or from public or private research centers.
L'archive ouverte pluridisciplinaire HAL, est destinée au dépôt et à la diffusion de documents scientifiques de niveau recherche, publiés ou non, émanant des établissements d'enseignement et de recherche français ou étrangers, des laboratoires publics ou privés. 


\section{Accepted Manuscript}

Semipermeable membrane devices link site-specific contaminants to effects:

Part 1 - induction of cyp1a in rainbow trout from contaminants in prince william sound, Alaska

Kathrine R. Springman, Jeffrey W. Short, Mandy R. Lindeberg, Jacek M.

Maselko, Colin Khan, Peter V. Hodson, Stanley D. Rice

PII:

S0141-1136(08)00178-5

DOI:

10.1016/j.marenvres.2008.07.001

Reference:

MERE 3268

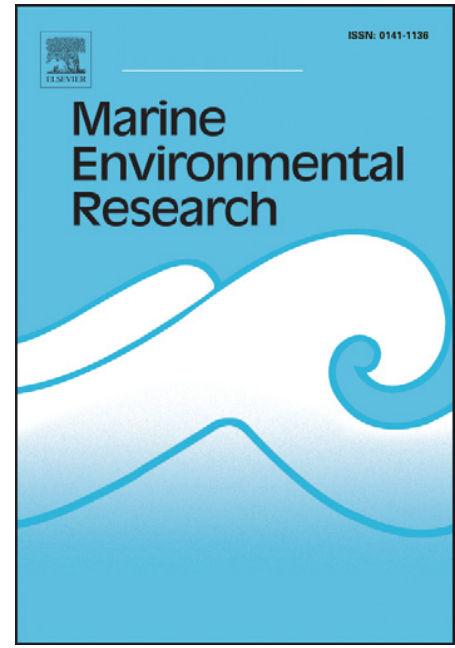

To appear in:

Marine Environmental Research

Received Date:

18 March 2008

Revised Date:

26 June 2008

Accepted Date:

1 July 2008

Please cite this article as: Springman, K.R., Short, J.W., Lindeberg, M.R., Maselko, J.M., Khan, C., Hodson, P.V., Rice, S.D., Semipermeable membrane devices link site-specific contaminants to effects: Part 1 - induction of cyp1a in rainbow trout from contaminants in prince william sound, Alaska, Marine Environmental Research (2008), doi: 10.1016/j.marenvres.2008.07.001

This is a PDF file of an unedited manuscript that has been accepted for publication. As a service to our customers we are providing this early version of the manuscript. The manuscript will undergo copyediting, typesetting, and review of the resulting proof before it is published in its final form. Please note that during the production process errors may be discovered which could affect the content, and all legal disclaimers that apply to the journal pertain. 
1 SEMIPERMEABLE MEMBRANE DEVICES LINK SITE-SPECIFIC CONTAMINANTS

2 TO EFFECTS: PART 1 - INDUCTION OF CYP1A IN RAINBOW TROUT FROM

3 CONTAMINANTS IN PRINCE WILLIAM SOUND, ALASKA

4

5

KATHRINE R. SPRINGMAN*, JEFFREY W. SHORT ${ }^{1}$, MANDY R. LINDEBERG ${ }^{1}$, JACEK

M. MASELKO ${ }^{1}$, COLIN KHAN $^{2}$, PETER V. HODSON ${ }^{2}$, STANLEY D. RICE $^{1}$

${ }^{1}$ Auke Bay Laboratory, Alaska Fisheries Science Center, National Marine Fisheries Service,

NOAA, 11305 Glacier Highway, Juneau, Alaska 99801-8626 USA

${ }^{2}$ Queen's University, Kingston, Ontario, K7L 3N6 Canada

16

$18 *$ Corresponding author contact information:

19 Telephone: 530-400-4141; fax: 707-937-6212; e-mail: krspringman@gmail.com

20 Current address: P.O. Box 315, Littleriver, CA 95456 
Abstract

Extracts from semi-permeable membrane devices (SPMDs) deployed on beaches in

29 Prince William Sound (PWS), Alaska, were used to evaluate if complex contaminant mixtures

30 from different sources can be distinguished by the resulting cytochrome P450 1A (CYP1A)

31 activity in exposed test animals. Deployment sites included canneries, salmon hatcheries, and

32 beaches where lingering oil remains from discharges during the 1964 earthquake or the 1989

33 Exxon Valdez oil spill. Other sites were selected at random to evaluate region-wide contaminant

34 inputs or were located in salmon streams to evaluate contaminants carried and released by

35 migrating salmon carcasses following reproduction. Following standard deployments of

36 approximately $28 \mathrm{~d}$, an aliquot of the accumulated contaminants was intraperitoneally injected

37 without cleanup into juvenile rainbow trout (Oncorhynchus mykiss). After $2 \mathrm{~d}$ and $7 \mathrm{~d}$, the

38 activity of CYP1A was measured by the ethoxyresorufin-o-deethylase (EROD) assay. Exposure

39 to extracts from the oiled sites and one hatchery site with numerous creosote pilings elicited

40 strong EROD responses, whereas fish exposed to salmon stream extracts elicited weak but

41 significant responses during late summer compared to late spring. Responses from the other

42 sites were not significant, indicating contaminants from these sources are unlikely to cause

43 CYP1A induction in resident biota. Rather than simply assessing extant contaminants, this

44 method evaluates the potency of the different sites for bringing about aryl hydrocarbon receptor

45 responses in resident biota.

\section{1. Introduction}


Biochemical responses can be sensitive indicators of pollution exposure. Such responses,

50 termed biomarkers, are indicators in biological fluids, cells or tissues signaling modifications in

51 the biological system due to contaminants (NRC 1987). Biomarker responses have been

52 extensively investigated and provide a convenient and toxicologically relevant means of

53 detecting exposure to low concentrations of contaminants (Dickerson et al., 1994). While

54 biomarkers may indicate exposure to specific classes of contaminants, these responses may

55 provide little information regarding the contaminant source, beyond that inferred from the

56 geographic and temporal patterns of biomarker expression (Short and Springman 2006). Even

57 the location of contaminant sources may be ambiguous when biomarkers are assessed in mobile

58 biota. Moreover, biomarkers usually do not account for chemical speciation or availability

59 (Bucheli and Fent 1995).

Biomarker expression can be linked more directly to contaminant sources via an

61 intermediary contaminant sampler such as semipermeable membrane devices (SPMDs). These

62 passive samplers may be deployed to concentrate lipophilic organic contaminants from

63 acknowledged or probable sources. At equilibrium with the exposure medium, SPMDs

64 accumulate contaminants according to their octanol-water partition coefficient $\left(K_{\text {ow }}\right)$ values

65 (Huckins et al., 2006). The contaminants retained in the SPMD are capable of membrane

66 passage, and as such are potentially a greater risk to biota. Once retrieved by dialysis, these

67 contaminants may be injected into test organisms such as fish, which can then be examined for

68 resulting changes. This relates the response expression to bioavailable contaminants present at

69 the deployment site. Previous studies have assessed the potency of cytochrome P450 1A

70 (CYP1A) in fish liver cells (PLHC-1) to inducers absorbed by environmentally exposed SPMDs

71 (Parrott et al., 1999; Villeneuve et al, 1997). Sundberg et al., (2005) injected trout eggs with 
72 fractionated SPMD extracts to evaluate the induction potency of different contaminant classes

73 found in a region where a single point source was dominant. In all these studies, the

74 contaminants recovered from the SPMDs were purified by silica gel chromatography or other

75 means to facilitate chemical analysis prior to their use for the biological assays. Because

76 purification may remove contaminants that affect the selected biomarker, none of these methods

77 assess the induction potential of the environment per se, but only the target contaminants of the

78 study. Our aim in this work is to extend these earlier methods to evaluate the CYP1A-induction

79 potential of all nonpolar, lipophilic contaminants absorbed by SPMDs deployed in the

80 environment under study by injecting recovered contaminants into juvenile rainbow trout

81 without clean-up.

82 In situations where multiple contaminant sources are plausible, the biomarker response of

83 injected contaminants extracted from SPMDs provides a method of evaluating the relative

84 potency of different sources. The biomarker response of animals injected with the SPMD extract

85 provides an indication of the induction potency of contaminants from the source(s) sampled by

86 the deployed SPMD. This approach quantifies the biochemical effect triggered by the mixture

87 of nonpolar compounds as a group, and does not require identification of the particular

88 contaminants causing induction. This may be a considerable advantage in cases where a positive

89 biomarker response is evident in resident biota, multiple potential sources are present, and the

90 identity of the contaminants that are driving the biomarker response is not apparent.

$91 \quad$ Prince William Sound (PWS), Alaska provided an excellent setting to test the utility of

92 this method. It is a sparsely populated region where relatively few candidate sources are

93 present, one of which is oil from the 1989 Exxon Valdez oil spill that is still found on beaches in

94 western PWS. This oil is a CYP1A inducer (Woodin et al., 1997). Induction of CYP1A has 
95 been reported in resident sea otters (Enhydra lutris) and harlequin ducks (Histrionicus

96 histrionicus) that frequent beaches where oil persists (Short et al., 2006, Bodkin et al., 2002,

97 Trust et al., 2000). However, confounding potential sources of CYP1A inducers are possible.

98 These include: (1) asphalt and heavy bunker fuels released from storage tanks damaged by the

991964 Alaska earthquake (Kvenvolden et al 1995); (2) fuel spills from commercial fishing,

100 marinas, salmon hatchery docks and other marine traffic (Page et al., 1999); (3) broad-scale

101 background pollutants from atmospheric deposition of persistent organic pollutants (Stern et al.,

102 1997); (4) polycyclic aromatic hydrocarbons (PAH) associated with oil seeps and erosion of

103 hydrocarbon-rich source rocks and coal outcrops (Short et al., 2004; Short et al., 1999; Page et

104 al., 1995); (5) PAH from forest fires (Page et al., 1999); (6) contaminants from marine vessels

105 (Page et al., 1995); and (7) persistent organic pollutants associated with spawning migrations of

106 adult salmon returning to their natal streams (Krümmel et al 2003; Ewald et al., 1998).

107 Concerns regarding these potential sources of CYP1A inducers in the region continue to be

108 raised (Boehm et al., 2007, Huggett et al., 2006, Neff et al., 2006, Lee and Anderson, 2005, Page

109 et al., 2004, Huggett et al., 2003, Jewett et al., 2002). Injecting fish with extracts from SPMDs

110 and measuring their CYP1A activity provides a way of identifying which sources are capable of

111 stimulating a response. Those that do not, can be eliminated as causes of the CYP1A induction

112 observed in wildlife in that region.

113 Here, we extended the approach used by Sundberg et al. (2005) to evaluate which

114 pollution sources in PWS were capable of stimulating CYP1A induction. In fish, the activity of

115 this enzyme, as determined with the ethoxyresorufin-o-deethylase (EROD) assay, is an

116 established biomarker of exposure to PAH and structurally related compounds. The activity of

117 this enzyme is particularly suited to monitor discharges of petroleum or other PAH sources, co- 
118 planar polychlorinated biphenyls (PCB), and dioxins (Whyte et al., 2000; Stegeman and Hahn

119 1994). Our overall objectives were to identify which of these sources contained compounds that

120 induced CYP1A in exposed biota, and to determine which of the bioavailable hydrocarbons were

121 responsible. We report our results in two parts. Here (Part I), our objectives are to describe and

122 validate the method, which includes an assessment of the precision, sensitivity, and dynamic

123 range. We present the results of our field deployments of SPMDs in PWS to evaluate the

124 CYP1A induction potential of prospective contaminant sources. In Part II, (Short et al., 2008),

125 we relate the CYP1A induction results to the chemical composition of the contaminants

126 accumulated by the SPMDs.

128 2. Methods

Prince William Sound is a complex, fjord-type ecosystem with a sea surface area of about

$1338,800 \mathrm{~km}^{2}$ (Schmidt 1977). Most of its 7,000 inhabitants reside in Cordova, Valdez or Whittier

134 (Fig. 1), while fewer than 200 live in the vicinity of Chenega or the regional salmon hatcheries.

135 The latter group is near the path followed by oil released by the T/V Exxon Valdez during the oil 136 spill in 1989. Past industrial activities within the spill path were sporadic. These include 2 large 137 mine sites at Latouche, 6 fish processing plants, and a number of smallholdings devoted to 138 mineral prospecting, artisanal sawmills and fur-farming. All of these were abandoned during the 139 mid-20 ${ }^{\text {th }}$ century (Wooley 2000). Current industrial activities include the Alyeska oil terminal in 
140 Port Valdez, commercial fishing and oyster farming, 5 large salmon hatcheries, and seasonal

141 tourism.

142 We deployed SPMDs to evaluate the CYP1A induction potential of 6 classes of

143 contaminant sources: (1) lingering, subsurface, Alaska North Slope (ANS) oil from the Exxon

144 Valdez oil spill ( $N=5$ sites, 3 of which were replicated); (2) human activity $(N=6)$ sites,

145 including an abandoned industrial site with Monterey Formation bunker oil from storage tanks

146 damaged by the 1964 Alaska earthquake; (3) salmon hatcheries $(N=5)$; (4) salmon streams $(N$

$147=5$ ), because salmon carcasses can release accumulated CYP1A-inducing pollutants as they

148 decompose in their natal streams following reproduction; (5) random sites $(N=9)$ to evaluate

149 area-wide pollution sources including atmospherically transported contaminants; and (6) a site at

150 Constantine Harbor where PAH associated with organic-rich rocks eroded from geologic sources

151 east of PWS are incorporated into the intertidal sediments (Short et al., 1996). At the ANS sites,

152 we deployed additional SPMDs at adjacent paired control sites to account for local inducing

153 agents other than ANS. We also deployed SPMDs at a remote site at Graves Harbor in southeast

154 Alaska $300 \mathrm{~km}$ east of PWS and upcurrent of the geological hydrocarbon sources to serve as a

155 negative regional field control site, and at Cordova Harbor to serve as a positive field control.

156 The SPMDs were deployed at most sites in spring from mid-May to mid-June 2004, prior

157 to the annual spawning migration of salmon. At the salmon stream sites, they were again

158 deployed in summer from mid-August to mid-September 2004, after adult salmon had returned

159 to spawn. Five of the random site deployments were during spring, and the other 4 during

160 summer to assess region-wide seasonal differences. The random selections for these sites were

161 made within each of 5 sectors partitioning PWS (see Fig. 1 in Short et al., 2008). Each sector 
162 was allocated 1 or 2 sites to ensure dispersion, and each site was located on a randomly-selected

163 shore segment within a sector as described in Part II (Short et al., 2008).

\subsection{Semipermeable membrane devices}

166

The SPMDs were obtained from Environmental Sampling Technologies (St. Joseph, MO),

168 and deployed in $30 \mathrm{~cm}$ long cylindrical cages, each loaded with 5 SPMDs woven on stainless

169 steel carriers stacked within the cage. Each SPMD had dimensions of $91.4 \times 2.5 \mathrm{~cm}$ and

170 contained $1 \mathrm{ml}$ of ultra-high purity (UHP) triolein. The cages were half buried in pits excavated

171 at the mid-tide level of deployment site shorelines. After placement in a pit, the excavated

172 material was replaced to the level of the beach surface, surrounding, but not covering, the cage.

173 This arrangement allowed the SPMDs to sample the atmosphere at low tide (Lohmann et al.,

174 2001, Ockenden et al., 1998), surface seawater at high tide, and interstitial water flow within the

175 upper $15 \mathrm{~cm}$ of beach while minimizing biofouling. Cages were deployed for the standard 176 deployment period of $27-28$ days, then retrieved for dialysis. At the ANS and human activity

177 sites where contamination was greater, the cages were placed in patches of subsurface oil to

178 ensure uptake of organic contaminants. A field blank cage with 5 UHP SPMDs was briefly

179 exposed to the atmosphere during two of the deployments and then stored for dialysis.

\subsection{SPMD processing}

182

Contaminants were recovered by dialysis into hexane at the laboratory of Environmental

184 Sampling Technologies, following physical removal of external sediment and biofouling as per 
185 Huckins et al. (2000). The dialysates from all 5 SPMDs within a cage were pooled. Following

186 concentration of the combined dialysates to $\sim 1 \mathrm{ml}$, samples were sent to Auke Bay Laboratory in

187 sealed ampules. The contents were partitioned into subsamples for chemical analysis (3 aliquots

188 each containing $5 \%$ of the dialysate) and for injection into juvenile trout for CYP1A induction (2

189 aliquots, each with $42.5 \%$ of the dialysate). One each of the aliquots for injection and for

190 chemical analysis were archived in the event of accidental losses. Results of the chemical

191 analysis of the dialysates are presented in Part II (Short et al., 2008). The aliquot used for

192 injection was exchanged into peanut oil (Spectrum Chemical Mfg., Gardena, CA) under nitrogen

193 at $\sim 35^{\circ} \mathrm{C}$. Samples for induction tests were coded with un-informative sample identification

194 numbers and sent to California for blind bioassay.

195 Quality assurance samples included field and dialysis blanks, a solvent control, and a

196 positive laboratory control ( $\beta$-naphthoflavone or BNF, a model CYP1A inducer). The $\beta$ -

197 naphthoflavone was suspended in peanut oil and doses of $2.5 \mathrm{mg} \mathrm{kg}^{-1}$ were prepared for three

198 fish weight classes, $\leq 7.5 \mathrm{~g}, 7.5-10.0 \mathrm{~g}, \geq 10.0 \mathrm{~g}$, to maintain a uniform injection volume of $50 \mu \mathrm{l}$

199 fish $^{-1}$.

200

2012.4 Animal Exposure

202

Juvenile rainbow trout (Oncorhynchus mykiss), Mount Shasta strain, average weight 9.2

$204 \pm 2.6 \mathrm{~g}$, were obtained from California Department of Fish and Game Mount Shasta Hatchery.

205 They were maintained at $13 \pm 1^{\circ} \mathrm{C}$ in aerated, flow-through water systems for at least a week

206 prior to testing and fed a commercial diet (Silver Cup, \#3, Nelson \& Sons Inc., Murray, UT) until

207 the day prior to dosing. 
The dialysate aliquot from each sample was partitioned further into 10 sub-aliquots, each

209 injected into a single juvenile trout, so each trout received 4.2\% of the dialysate from an SPMD

210 deployment in a $50 \mu$ injection. For each sample, 10 fish were anesthetized in a solution of $\sim 50$

$211 \mathrm{mg}^{-1}$ tricaine methane sulfonate (MS222) and injected intraperitoneally (i.p.) with the extract.

212 Many compounds can induce CYP1A, including planar hydrocarbons that meet the

213 requisite structural criteria, but these compounds may reach peak induction at different times.

214 The positive control, $\beta$-naphthoflavone $(\mathrm{BNF})$, is at its peak induction $\sim 48 \mathrm{~h}$ after i.p. injection in

215 rainbow trout, which is similar to the response from PAHs in this species (Lemaire et al., 1996).

216 Of 209 polychlorinated biphenyls (PCBs), those that can induce CYP1A strongly in rainbow

217 trout show peak induction at 6 d following i.p. injection (Huuskonen et al., 1996). We sacrificed

2185 fish of each group in an overdose of MS222 at $2 \mathrm{~d}$ to examine the CYP1A responses of those

219 compounds that are metabolized more readily, such as PAH, while allowing the remaining 5 fish

$2207 \mathrm{~d}$ until sacrifice to evaluate effects from compounds which reach peak induction later, such as

221 PCBs. The weight and standard length of each individual were recorded, and the liver excised

222 and frozen in liquid nitrogen within two minutes of death. This was repeated with the remaining

2235 fish from each group at 7 d post-injection. The livers were shipped frozen to Queen’s

224 University, Kingston, Ontario, Canada for evaluation of CYP1A induction.

\subsection{EROD bioassay}

CYP1A induction was estimated by measuring the activity of ethoxyresorufin- $o$ -

229 deethylase (EROD), based on an original method by Pohl and Fouts (1980) modified for a

230 microplate spectrofluorometer (Hodson et al., 1996). Liver samples stored at $-84^{\circ} \mathrm{C}$ were 
231 thawed on ice and a sub-sample of 15-60 mg was homogenized in 500 - 750 $\mu \mathrm{L}$ of ice-cold 20

$232 \mathrm{mM}$ Na-HEPES buffer in $150 \mathrm{mM} \mathrm{KCl}(\mathrm{pH} 7.5)$. Homogenates were centrifuged for 20 minutes

233 at $2^{\circ} \mathrm{C}$ and $9000 \times \mathrm{G}$, and the supernatant and microsome layer (S-9 fraction) were recovered and

234 stored at $-84^{\circ} \mathrm{C}$. Each S-9 fraction was thawed on ice and triplicate aliquots of $50 \mu \mathrm{L}$ were

235 incubated with $50 \mu \mathrm{L}$ of $2.2 \mu \mathrm{M}$ 7-ethoxyresorufin in $100 \mathrm{mM}$ HEPES buffer (pH 7.8) in a 96-

236 well microplate held in the dark for 10 minutes at room temperature. The reaction was initiated

237 with $10 \mu \mathrm{L}$ of $1.1 \mu \mathrm{M}$ of NADPH. Fluorescence of resorufin, the reaction product, was

238 measured every minute for 12 minutes at excitation and emission wavelengths of 530 and 586

239 nm with a SpectraMax Gemini spectrofluorometer (Molecular Devices, Sunnyvale CA, USA).

240 Crude activity was estimated as the rate of increase in fluorescence and converted to a molar

241 basis by reference to a resorufin standard curve (0-20 pM) included with each plate. Molar

242 specific activity (picomole resorufin per $\mathrm{mg}$ protein per minute; $\mathrm{pmol} \mathrm{mg} \mathrm{protein}{ }^{-1} \min ^{-1}$ ) was

243 calculated by normalizing crude activity to S-9 protein concentrations. Protein was determined

244 against a standard curve of bovine serum albumin (0-2.5 $\left.\mathrm{mg} \mathrm{l}^{-1}\right)$ by mixing $10 \mu \mathrm{L}$ of each S-9

245 fraction with $200 \mu \mathrm{L}$ of Biorad Reagent (Biorad, Hercules, CA, USA) and measuring absorption

246 at $600 \mathrm{~nm}$ with a SpectraMax Plus spectrophotometer (Molecular Devices, Sunnyvale CA,

247 USA). Data were acquired and analyzed with Molecular Devices SOFTMAX PRO software.

248 Samples were analyzed blind, and the analytical batches were composed of samples selected at 249 random.

2512.6 Data analysis 
254 deployment device is presented as the antilog of the logarithmic mean EROD value of the 5 fish

255 injected for each time group $(2 \mathrm{~d}$ and $7 \mathrm{~d})$. The logarithmic data transformation is used as the

256 EROD activities are log-normally distributed (Hodson et al. 1996), justifying parametric

257 statistical comparisons. Consequently, following logarithmic transformation, we used analysis

258 of variance (ANOVA) to assess the significance of differences between EROD values. Groups

259 of SPMD results within contaminant source classes are presented as the mean for individual

260 SPMD deployments. Variation is based on the logarithmic standard error, presented as the

261 antilog, which gives an asymmetric interval.

262 To clarify notation in these statistical tests, we use " $N$ " to represent the number of sites in

263 a class, as described in Section 2.1. Because the number of individuals compared is the number

264 of fish injected, we use " $n$ " to denote the number of fish within a group, and " $m$ " to denote the

265 number of SPMDs that were used to prepare the extract for that group. Although 5 fish were

266 usually injected with the equivalent of an extract aliquot from one SPMD, the number of

267 corresponding EROD analyses was occasionally fewer because of processing errors, and greater

268 in some cases because all the extract was used to evaluate the response at $2 \mathrm{~d}$.

270 3. Results and Discussion

271

2723.1 Analytical Performance

273

274 The ability of the method to detect and distinguish contaminant burdens injected into the

275 juvenile trout depends on the sensitivity, precision, and dynamic range of the EROD response, 
276 which are demonstrated by the laboratory and field control treatments. The basal EROD activity

277 of unhandled fish, $0.932 \mathrm{pmol} \mathrm{mg}$ protein ${ }^{-1} \min ^{-1}$ (Table 1), defines the minimum activity

278 expected in the absence of stress. Injection of the peanut oil solvent caused a significant

279 doubling of activity after $2 \mathrm{~d}(P=0.002)$, subsiding by $7 \mathrm{~d}$ to a level not significantly different

280 than the basal activity $(P=0.56$; Table 1$)$. The lower responses at $7 \mathrm{~d}$ compared with $2 \mathrm{~d}$ were

281 the result of recovery from the stress of the initial injection and handling (Lemaire et al., 1996,

282 Blom and Förlin, 1997). Consequently, increases that more than double the basal activity

283 following injection were probably the result of factors other than handling stress.

284 Injection of some of the field- and dialysis-blank SPMD extracts caused greater EROD

285 activity than expected from handling stress, suggesting low-level contamination introduced

286 during manufacture. The mean EROD activity of these blanks was twice that of the

287 corresponding activities caused by injection of peanut oil at $2 \mathrm{~d}$ and at $7 \mathrm{~d}$ (Table 1), both

288 significant increases $(P<0.05)$. Analysis of variance showed marginally significant differences

289 among the field blanks $(\mathrm{FB} ; m=4)$ at $2 \mathrm{~d}(P=0.063)$ and clearly significant differences at $7 \mathrm{~d}$

$290(P<0.001)$. The $7 \mathrm{~d}$ activities of one of the field blanks and one of the dialysis blanks were not

291 significantly different than their corresponding $2 \mathrm{~d}$ activities $(P>0.20)$, the other field blank and

292 dialysis blank are significantly lower $(P<0.01)$ at $7 \mathrm{~d}$. These results suggest that all the field

293 and dialysis blanks contained traces of contaminants capable of stimulating small increases in

294 EROD activity $2 \mathrm{~d}$ following extract injection, extending in some cases to $7 \mathrm{~d}$. Such low-level

295 traces of contaminants in un-deployed SPMDs have been noted previously by Boehm et al.,

296 (2005). However, the alkylated PAH recovered from SPMDs by Boehm et al. (2005) may have

297 been introduced as laboratory artifacts during their non-standard dialysis of the samplers

298 (Schwartz, 2006). 
Oleic acid, an impurity in the triolein used for SPMDs, may contribute to some of the

300 observed responses. The fraction containing these compounds has produced positive responses

301 in the Microtox assay (Sabaliûnas et al., 1999). However, Huckins et al. (2006) noted that while

302 deployed, any remaining oleic acid or methyl oleate impurities diffuse to the exterior surface of

303 the membrane where they are removed. This environmental release does not occur in quality

304 control SPMDs (field blanks and dialysis blanks), creating the potential for differential

305 responses. Purified (UHP) triolein substantially decreases these impurities (Lebo et al, 2003;

306 also, summary of SPMD screening in Supplementary Data), thus decreasing but not precluding

307 this risk, which could be magnified without sample cleanup. These results indicate that

308 additional purification of SPMDs may be necessary to achieve maximum sensitivity when the

309 contaminants are extracted, injected into fish and the EROD response measured. In our study,

310 this additional purification was provided by environmental exposure when SPMDs were

311 deployed at sites distant from obvious contaminant sources within PWS.

312 The low EROD responses produced by SPMDs deployed at random sites, Constantine

313 Harbor, regional field control and the local ANS control sites provide a robust estimate of the

314 precision of the method in the absence of contaminants. The mean EROD response for these

315 sites was not significantly different from the responses from the peanut oil injections at either $2 \mathrm{~d}$

316 or $7 \mathrm{~d}(P>0.47, m=16$; Table 1$)$, but were significantly below the corresponding field and

317 dialysis blank responses $(P<0.001)$. This indicates that impurities initially present in the

318 SPMDs had diffused into the environment during deployment, an effect that is also evident in

319 PAH data presented for reference sites in PWS presented by Boehm et al. (2005). As with the

320 peanut oil injections, the $2 \mathrm{~d}$ responses were significantly greater than the $7 \mathrm{~d}$ responses by a

321 factor of $2(P<0.001)$, confirming the effect of handling stress. Analysis of variance did not 
322 shows significant differences among the individual SPMDs at $2 \mathrm{~d}$ following injection $(P=$

323 0.318), but did at $7 \mathrm{~d}(\mathrm{P}<0.001)$, which we attribute to slight variation in fish responses to

324 handling stress.

325 Comparison of the positive and negative control samples illustrates the analytical range

326 of the method. The positive laboratory control dose of $2.52 .5 \mathrm{mg} \mathrm{kg}^{-1} \mathrm{BNF}$ is near the threshold

327 for immune system impairment in juvenile trout similar to those we used (Springman et al.,

328 2005), providing a biologically meaningful laboratory benchmark. The corresponding $2 \mathrm{~d}$ and 7

329 d EROD responses near 70 pmol mg protein ${ }^{-1} \min ^{-1}$ (Table 1) were about 40-fold greater than

330 the response from the peanut oil injection. The contaminants accumulated by the SPMDs

331 deployed at the Cordova Harbor field control site elicited about half the response of the BNF

332 dose (Table 1), confirming the ability of the method to detect CYP1A-inducing contaminants

333 when present. Cordova Harbor, a confined harbor with limited seawater exchange, is one of the

334 most polluted in the United States based on petroleum-derived contaminant concentrations in

335 mussels within the harbor (Miles et al., 2001).

336 The EROD responses of the rainbow trout we injected are comparable with responses

337 expected for feral fish and other biota occupying the environment of the deployed SPMD. A

338 valid comparison of induction from bioavailable CYP1A inducers depends on a comparable

339 absorption capacity in both fish and SPMD. Direct experimental comparison of uptake rates and

340 accumulated burdens for SPMDs vs. fish shows that SPMDs accumulate polychlorinated

341 biphenyls (PCBs) about twice as fast per gram SPMD as per gram wet fish tissue, resulting in

342 body burdens about twice as great (Echols et al., 2000; Meadows et al., 1998). With our method,

$34342.5 \%$ of the contaminants accumulated by $22.5 \mathrm{~g}$ of SPMDs was injected into 10 rainbow trout

344 of $9.2 \mathrm{~g}$ mean wet weight, so the effective ratio of SPMD to wet fish tissue is $1: 10$, which is 
345 comparable to that in Meadows et al. (1998). If lipophilic contaminants are accumulated twice

346 as fast by SPMDs than fish, then our fish received about one-fifth the body burden they would

347 have accumulated, had they been exposed to the deployment conditions of the SPMD that

348 produced the extract we injected into them. However, the entire complement of contaminants

349 accumulated by the SPMD during the $28 \mathrm{~d}$ SPMD deployment period was directly administered

350 to our naïve test fish. Assuming fish absorb, biotransform and eliminate xenobiotics according

351 to first-order kinetics, the time required to attain $20 \%$ of the equilibrium body burden when

352 exposed to a constant aqueous contaminant concentration is $\left(0.22 * t_{1 / 2} / 0.693\right)$, where $t_{1 / 2}$ is the

353 half-life of the contaminant in the fish (Meador et al., 1995). Half-lives of 3- and 4-ring PAH in

354 rainbow trout are 2 to 9 days (Niimi and Dookhran 1989; Niimi and Palazzo 1986), implying

$35520 \%$ accumulation within $0.6-2.9$ days. Even longer times would be required for more

356 persistent contaminants such as PCBs due to their longer half-lives. Our intraperitoneal injection

357 lead to complete absorption of contaminants within a few hours, and would therefore be about as

358 effective for stimulating CYP1A induction as placing the fish in the environment sampled by the

359 deployed SPMD. Consequently, it is unlikely that biota exposed to the same environment as our

360 deployed SPMDs would have CYP1A activities above their basal level if an injection of

361 contaminants from the SPMD fails to stimulate induction.

362 Having described the analytical performance and characteristics of our SPMD-extract

363 injection method, we now assess results from SPMD deployments at sites within or near obvious 364 local contaminant sources within PWS. 
The SPMDs deployed at the ANS sites consistently accumulated inducers responsible for

369

370

371

372

373

374

375

376

377

378

379

380

381

382

383

384

385 the strongest CYP1A responses of our study (Fig. 2). The overall mean response was 39 pmol mg protein ${ }^{-1} \min ^{-1}$ for $2 \mathrm{~d}$, significantly exceeding the ANS control site responses $(P<0.001)$. Mean responses for these sites ranged from $23-69 \mathrm{pmol} \mathrm{mg} \mathrm{protein}{ }^{-1} \mathrm{~min}^{-1}$. At one site where 3 SPMDs were deployed within 2 m of each other, the mean responses ranged from $24-36$ pmol mg protein ${ }^{-1} \min ^{-1}$, providing an indication of field reproducibility of the method. The consistency of the responses from the ANS sites shows that the lingering ANS oil remains a potent source of CYP1A-inducing compounds, and that those compounds are in a form that can be absorbed by SPMDs and presumably by biota. The subsurface oil patches where the SPMDs were deployed consisted of semi-liquid oil that readily produced surface sheens on contact with water, so the CYP1A inductive potential of the extracts derived from these deployments is not surprising, given the demonstrated CYP1A induction potency of ANS oil (Woodin et al., 1997). Induction of EROD activity persisted for $7 \mathrm{~d}$ following injection of SPMD extracts from most of the ANS sites (Fig. 2). The $7 \mathrm{~d}$ response was greater than the $2 \mathrm{~d}$ response at one of the sites on Disk Island, but otherwise were lower by factors of $2-3$ at 3 other sites, and by factors of $5-10$ at the remaining 2 sites (KN114A and KN109A). The results from the ANS sites suggest more complex interactions which incorporate site-specific characteristics, such as those found at Disk Island and areas of Knight Island (KN136A). Exposure to some forms of peat may induce CYP1A (Kopponen et al., 1993), and co-exposure to humic acids can modulate induction (Matsuo et al. 2006). These sites are located in areas where there is peat beneath the oil, and one of the Disk Island deployments was within a stream. The $2 \mathrm{~d}$ responses from all three sites (Fig. 2) are similar to each other and to other oiled sites. However, the $7 \mathrm{~d}$ responses corroborate the elevated CYP1A activity that results from co-exposure to humic substances and 
391 petroleum (Matsuo et al., 2006), in that the 7d response is more persistent at the Disk Island

392 location where the peat is not flushed by the surface stream. ANS sites received the same oil in

393 1989, yet the response elicited by bioavailable hydrocarbons in 2004 varies in persistence and

394 intensity from site to site. Such location-specific factors may sometimes affect the potential 395 toxicity of bioavailable PAH.

\subsection{Human Activity and Salmon Hatchery Sites}

The EROD responses from the human activity and salmon hatchery sites were usually

400 similar or only slightly greater than responses at the random and other uncontaminated sites (Fig.

401 3), with two exceptions: McClure Bay and Armin F. Koernig (AFK) hatchery. Excluding these 402 two sites, the mean $2 \mathrm{~d}$ and $7 \mathrm{~d}$ EROD responses of and salmon hatchery sources ranged from 1.9 $403-5.7$ pmol mg protein ${ }^{-1} \min ^{-1}(m=9, n=45)$ and from $1.3-2.9$ pmol mg protein ${ }^{-1} \min ^{-1}(n=$ 404 44), respectively. The responses that are significantly greater than those of the uncontaminated 405 sites are indicated in Fig. 3. These sites include surface patches of Monterey Formation asphalt 406 at Latouche, Port Ashton, Port Audrey and Thumb Bay, and unidentified contaminants near the 407 hatchery at Main Bay. At Latouche, the EROD response remained significantly elevated 408 through $7 \mathrm{~d}$.

410 potencies of the contaminants at most human activity and salmon hatchery sites are minor when

411 compared with induction potential from oiled ANS sites. This may be because either these

412 human activity and salmon hatchery contaminants are less bioavailable, or are not strong

413 inducers, or both. Page et al. (2006) reported substantial concentrations of PAH associated with 
414 asphaltic remnants of Monterey Formation bunker oil contaminating a total of $\sim 2.1$ ha of

415 surficial sediments at Latouche, Port Ashton, Port Audrey and Thumb Bay. Our results indicate

416 the CYP1A induction potency of these sediments is weak in contrast to lingering ANS oil

417 (compare Figs. 2 and 3). Latouche, Port Ashton, Port Audrey and Thumb Bay account for 95\%

418 of the total area contaminated by Monterey Formation bunker oil that also lies within the path of

419 the Exxon Valdez oil spill (Page et al., 2006). This combined area amounts to $\sim 20 \%$ of the area

420 contaminated by lingering Exxon Valdez oil (Short et al., 2004, 2008). The combination of

421 weaker induction and the smaller size of the combined Monterey Formation bunker oil spills

422 demonstrates these sources of EROD-inducing contaminants are minor in comparison with

423 lingering Exxon Valdez oil.

424 In contrast, SPMD extracts from the AFK hatchery and McClure Bay sites both produced 425 substantial EROD responses (Fig. 3), indicating the presence of stronger and more bioavailable

426 CYP1A inducing contaminants. The $2 \mathrm{~d}$ mean EROD responses are greater than $31 \mathrm{pmol} \mathrm{mg}$

427 protein $^{-1} \min ^{-1}$ and remained elevated after $7 \mathrm{~d}$, especially at McClure Bay, where the $7 \mathrm{~d}$

428 response was nearly half the $2 \mathrm{~d}$ response. The deployment site at AFK is near a large pier

429 supported by several hundred creosote pilings, and creosote pilings support numerous other piers

430 or their remnants within $\sim 1-2 \mathrm{~km}$ of the deployment site, unlike the other hatcheries where steel

431 or concrete pilings are in use. These creosote pilings are the likely source of the CYP1A-

432 inducing contaminants at AFK. Creosote contains numerous PAH that are potent CYP1A

433 inducers (Hyötyläinen and Oikari 1999) and the large surface area of the pilings near the AFK

434 deployment site would promote dissolution of PAH into surrounding waters. Similarly, the

435 SPMD deployment at McClure Bay was within a patch of semi-liquid, subsurface Monterey

436 Formation bunker fuel oil that was released from a nearby storage tank ruptured during the 1964 
437 Alaska earthquake. In contrast with surficial deposits of Monterey Formation asphalt at the

438 other human activity sites, the EROD response from the McClure Bay deployment shows that

439 burial can impede weathering such that the associated contaminants remain readily bioavailable

440 after 40 years. This corroborates the continuing bioavailability of contaminants associated with

441 the ANS oil, as well as the extraordinary persistence of remaining ANS oil (Short et al., 2004,

442 2008). Also, the elevated 7 d EROD responses confirms our results from the oiled ANS sites, in

443 that prolonged EROD responses are associated with this hydrocarbon source as well.

444 The prolonged, increased EROD responses from SPMD extracts deployed at some sites

445 suggests possible interactive effects, since elevated $7 \mathrm{~d}$ EROD activity occurs only at those sites

446 with a history of hydrocarbon exposure. For example, PAH oxidation may contribute to CYP1A

447 induction at favorable sites for microbial growth. This prolonged EROD response may increase

448 the duration that significant EROD responses are detectable in monitored, mobile biota exposed

449 to lingering oil in PWS, such as sea otters (Bodkin et al., 2002), and harlequin ducks (Trust et al. 450 2000).

\subsection{Salmon Streams}

The EROD responses from the summer SPMD deployments in the 5 salmon streams

455 consistently exceeded those of the spring deployments, implying slight seasonal variability at

456 these sites. The $2 \mathrm{~d}$ and $7 \mathrm{~d}$ responses from salmon stream spring deployments are not

457 significantly different $(P>0.105)$ than the respective responses from the random sites sampled

458 in spring (Fig. 4). In contrast, the $2 \mathrm{~d}$ and $7 \mathrm{~d}$ responses from summer deployments, averaged

459 over the 5 salmon stream sites, are 3.6 and 2.0 pmol mg protein ${ }^{-1} \min ^{-1}(n=25)$, which are $41 \%$ 

and $44 \%$ greater than respective responses from the random sites sampled during summer $(P<$

461 0.036). The increases of the $2 \mathrm{~d}$ responses are consistent for all 5 salmon streams, and for 4 of

462 the streams for the $7 \mathrm{~d}$ responses. The increase during late summer but not during late spring

463 indicates a seasonally transient input that subsides from late summer to the following spring.

464 This summer increase is localized to the salmon streams. Differences between random site

465 deployments during spring compared with summer are not significant $(P>0.15$; Fig. 4$)$ and are

466 within the range of responses from peanut oil injections. Thus the seasonal increase observed at

467 the salmon stream sites is probably not the result of a region-wide contaminant input. The

468 timing of this increase is in agreement with contaminants released from decomposing salmon

469 carcasses, following their migration to their natal stream to reproduce.

The consistent absence of CYP1A induction following injection of contaminants

474 extracted from our random and control site SPMDs into juvenile trout shows that the

475 contaminant background is a negligible source of dissolved, lipophilic CYP1A inducers in PWS.

476 Background contaminants are by definition broadly distributed, so they should routinely cause

477 induction if they include CYP1A inducers. But our results show that none of the $m=16$ SPMD

478 deployments at random and control sites elicited CYP1A induction above the stress caused by

479 peanut oil injection, and that deployment at these sites actually removed CYP1A inducing

480 compounds that were initially present in the SPMDs at deployment. We therefore conclude that,

481 apart from small, localized pollution sources that are usually readily identifiable (e.g. creosote

482 pilings, remnant oil deposits from the 1964 earthquake or the 1989 Exxon Valdez oil spill, etc.), 
483 the marine waters of PWS are among the least contaminated coastal waters with respect to 484 dissolved, lipophilic CYP1A inducers.

The low levels of dissolved CYP1A-inducing contaminants in the marine waters of PWS

486 implied by our random and control site results are consistent with most other studies of

487 contaminants in the region. As reviewed recently by Boehm et al. (2007), measured background

488 concentrations of total PAH in the marine waters of PWS are usually less than $20 \mathrm{ng} \mathrm{L}^{-1}$ (often

489 near or below the detection limits of the methods used), nearly all of which are 2- and 3-ring

490 PAH that are not potent CYP1A inducers (Barron et al., 2004). The SPMDs deployed by Boehm

491 et al. (2005) on the beach surface at their reference site contained a mean total PAH amount of

$49239 \mathrm{ng} \mathrm{SPMD}{ }^{-1}$, implying aqueous concentrations in the neighborhood of $1 \mathrm{ng} \mathrm{L}^{-1}$, again with

493 compounds capable of inducing CYP1A likely to be a very small proportion. In a survey of

494 PAH bioavailability at PWS sites oiled by the 1989 Exxon Valdez oil spill, Neff et al. (2006)

495 measured PAH concentrations of sea lettuce (Ulva fenestrate), reasoning that the mucilaginous

496 surface coating of this macroalgae would efficiently collect dissolved and particle-bound PAH

497 from seawater at higher tides and from the atmosphere at lower tides, much as our SPMDs

498 absorbed dissolved PAH from these media. They found mean concentrations of $11.3 \mathrm{ng} \mathrm{g}^{-1}$ dry

499 wt., again implying ambient total PAH concentrations below $1 \mathrm{ng} \mathrm{L} \mathrm{L}^{-1}$ (assuming a wet:dry wt

500 ratio of 10:1, and an effective $K_{o w}$ of $10^{4}$ ). In a study of PAH in lipid-rich copepods in central

501 PWS, Carls et al. (2006) found total PAH of $409 \mathrm{ng} \mathrm{g}^{-1}$, entirely of 2- and 3-ring PAH, and

502 equivalent to aqueous total PAH concentrations below about $20 \mathrm{ng}^{-1}$. Finally, the PAH

503 concentrations detected in the SPMDs deployed at the random and control sites of this study also

504 imply ambient dissolved total PAH concentrations in the low $\mathrm{ng} \mathrm{L}^{-1}$ range, with the more potent

505 CYP1A inducers such as PCBs and chrysenes usually below their quantitation limits in the 
SPMDs (Short et al., 2008). These studies all indicate ambient concentrations of the more potent

507 CYP1A inducers such as chrysene that are well below $1 \mathrm{ng} \mathrm{L}^{-1}$ in the marine waters of PWS, and

508 hence well below concentrations that might plausibly stimulate a background elevation of

509 CYP1A in PWS biota.

Neff et al. (2003) concluded that background PAH in deep-water sediments of PWS are

511 bioavailable based on differences in concentration patterns detected in polychaete worms (Nereis

512 virens) following prolonged exposure, but the supporting evidence presented is equivocal. The

513 PAH burden of the polychaete worms declined during exposure to the PWS sediments, were near

514 typical detection limits of the method used, and no evidence of statistical significance was

515 reported, suggesting the PAH pattern differences may simply reflect analytical variability.

$516 \quad$ Huggett et al. (2003) and Page et al. (2004) have argued that marine fish in the northern

517 Gulf of Alaska are chronically exposed to CYP1A-inducing hydrocarbons derived from oil seeps

518 and eroding hydrocarbon source rocks, but this conclusion seems premature. Their argument is

519 based on detecting measurable liver EROD responses in 4 species of fish, and fluorescent

520 aromatic compounds (FAC) in their bile. However, these authors failed to consider the

521 possibility that the low values they reported are merely the basal responses for the fish species

522 they tested. A thorough familiarity of this endogenous activity is necessary for accurate

523 interpretation of EROD induction. Of several biomarkers examined in 15 species of fish, EROD

524 induction showed the most variable basal activity between species (Förlin et al., 1995). An

525 accurate determination of the factors that can modulate it is a central concern when using this

526 biomarker to gauge contaminant impacts (Flammarion and Garric, 1997). Basal activity levels

527 were not reported for any of the fish species tested by Huggett et al. (2003), so there is no basis

528 for evaluating the significance of the EROD activities they presented. Similarly, the bile FAC 
529 responses for a single fish species considered by Huggett et al. (2003) show a marginally

530 significant increase above three samples from the lower of two reference sites that were collected

531 a decade earlier by different researchers and analyzed by a different laboratory. Moreover, the

532 identity of the compounds that caused the bile FAC response, presumably peaks within the same

533 HPLC retention time interval as 3-ring PAH conjugates, is not clear. Unfortunately, Huggett et

534 al. (2003) failed to verify the fluorescent compounds they detected in their bile samples as

535 conjugates of PAH by gas chromatography-mass spectrometry (Krahn et al.1992). These peaks

536 may have been interferences from naturally occurring compounds (Krahn et al. 1984), including

537 naturally occurring PAH such as retene (Lipiatou and Saliot 1992, 1991), or the metabolites of

538 organic pigments ingested during feeding. Also, the fish sampled were not controlled for sex,

539 age, reproductive status or differences in recently ingested prey, which may affect bile FAC

540 results (Collier and Varanasi 1992). Indeed, it appears that the basal response for bile

541 fluorescent compounds has not been established unequivocally for any species, making

542 interpretation of the evidence presented by Huggett et al. (2003) and Page et al. (2004)

543 problematic.

$544 \quad$ Woodin et al. (1997) did detect a slight but apparently significant increase in liver EROD

545 responses in an intertidal fish (gunnel, Anoplarchus purpurescens) collected from two reference

546 areas in PWS compared with basal responses, but it is not clear whether this CYP1A-inducing

547 agent was from a widespread background source or from undetected localized sources.

548 Overall, it seems unlikely that marine sediments contaminated by PAH from natural

549 petrogenic sources are capable of causing significant CYP1A induction in biota, when the extract

550 from the SPMD deployed at the Constantine Harbor failed to do so following injection into

551 juvenile trout. This deployment site is a mudflat containing $~ 560 \mathrm{ng} \mathrm{PAH} \mathrm{g}^{-1}$ sediment derived 
552 entirely from the eroded geologic sources (Short et al., 1996), and this concentration is within a

553 factor of 3 of the greatest background concentration found anywhere within PWS (Page et al.,

554 1996). The failure to accumulate sufficient PAH to stimulate a detectable EROD response when

555 injected, after deployment of the SPMD in intimate contact with the Constantine Harbor

556 sediments for nearly a month with the Constantine Harbor sediments, is strong evidence that the

557 PAH associated with these sediments is not sufficiently bioavailable to induce CYP1A in

558 exposed biota. Also, the general absence of EROD responses from SPMDs deployed at random

559 and control sites is consistent with the low intensity of human impacts (apart from the Exxon

560 Valdez oil spill) in PWS. Although human activities have affected scores of sites within PWS

561 (Page et al., 2006; Wooley, 2000), most of these sites were either concentrated around Sawmill

562 Bay or else were smallholdings that usually impacted less than $100 \mathrm{~m}$ of shoreline each. These

563 impacts were distributed over more than a century and their cumulative total affects less than

$5640.2 \%$ of the present day shoreline in PWS (Boehm et al., 2004). These small scale impacts,

565 coupled with a low population density, results in fewer and more localized contaminant sources.

566 The absence of CYP1A-inducing contaminants in our SPMDs from random and control sites is

567 therefore not surprising.

569 4. Conclusions

The results of this study demonstrate the value of SPMD dialysate injection for

572 elucidating contaminant sources and exposure effects. Method sensitivity is illustrated by the

573 small but significant differences among EROD responses, such as those between spring and

574 summer salmon stream EROD activities. Significant EROD induction occurs following injection 
575 of dialysates from SPMDs exposed to part per trillion aqueous concentrations of potent inducers,

576 especially chrysenes (Short et al., 2008). This shows that the SPMD/EROD assay as described

577 in this study to be a cost-effective method for detecting these contaminants in comparison with

578 direct chemical analysis of the dialysate. Another advantage over direct chemical analysis is that

579 the identity of the EROD-inducing agents need not be known. Instead, this method assesses the

580 inductive potential of the bioavailable complex mixture, with all its inherent interactions, at a

581 given site. The dynamic range is sufficiently large to indicate contamination gradients that may

582 suggest sources, and to quantify the effects of the bioavailable contaminant fraction following

583 direct exposure. Method reproducibility is demonstrated by the biochemical responses from the

584 oiled sites, particularly EL56C where the replicates were 2 meters apart, and the apparent

585 absence of false negatives. Thus, the method provides a reliable means of evaluating exposure

586 to the bioavailable fraction of hydrophobic contaminants, as the response elicited is based on the

587 absorption of contaminants into the SPMD, which serves as a standardized surrogate for local

588 biota.

589 This method overcomes potential drawbacks associated with biomarkers when compared

590 to chemical analysis, as presented by Forbes et al. (2006), including cost, relevance, sensitivity,

591 reproducibility, and consistency. Technological advances, such as enzyme-linked

592 immunosorbent assay (ELISA) columns and assay kits, have led to substantial increases in ease

593 of use for EROD and other biomarkers. The EROD assay is relatively simple in both method

594 and required equipment; by comparison, determination of chemical residues in tissue or

595 environmental samples is much more complex and equipment-intensive, leading to higher per

596 sample costs than those spent on biomarkers (Dickerson, 1994; EPA, 1986). For each site in this

597 study, the cost of EROD assays was about $16 \%$ of that for chemical analyses. Finally, this 
method allows an assessment of the total contribution of the complex mixture that can be taken up by the targets, whether these compounds are detected analytically or not. The SPMD extract injection method complements field testing of biota from

601 contaminated areas. This method measures the response that the bioavailable contaminant 602 fraction can produce with few confounding variables such as gender, age, reproductive status or

603 condition. CYP1A induction was selected here as it is a well-established biomarker of PAH 604 exposure. For breadth of applicability, the test organism we used is an appropriate choice as 605 rainbow trout P450 systems may be as complex as their mammalian counterparts (Buhler and

606 Wang-Buhler 1998). Ultimately, the suspected non-polar contaminants and the potential targets

607 determine which response(s) to measure and which test organism to use, but the method

608 presented here is flexible and can accommodate other types of analysis and different test 609 animals.

\section{Acknowledgements}

614 This study was supported in part by the Exxon Valdez Oil Spill Trustee Council, but the findings

615 and conclusions are those of the authors and do not necessarily reflect the views or positions of

616 the Council. Mention of products or services herein does not imply endorsement by the US

617 government.

619 References 
621 Barron, M.G., Heintz, R., \& Rice, S.D. (2004). Relative potency of PAHs and heterocycles as aryl hydrocarbon receptor agonists in fish. Marine Environmental Research, 58, 95-100.

Blom, S. \& Förlin, L. (1997). Effects of PCB on xenobiotic biotransformation enzyme activities in the liver and 21-hydroxylation in the head kidney of juvenile rainbow trout. Aquatic

Bodkin, J.L., Ballachey, B.E., Dean, T.A., Fukuyama, A.K., Jewett, S.C., McDonald, L., Monson, D.H., O'Clair, C.E., \& VanBlaricom, G.R. (2002). Sea otter population status and Toxicology, 39, 215-230.

Boehm, P.D., Page, D.S., Brown, J.S., Neff, J.M., \& Burns, W.A. (2004). Polycyclic aromatic hydrocarbon levels in mussels from Prince William Sound, Alaska, USA, document the return to baseline conditions. Environmental Toxicology and Chemistry, 23, 2916-2929. exposure in the waters of Prince William Sound after the Exxon Valdez oil spill: 19892005. Marine Pollution Bulletin, 54, 339-367. 
642 Buhler, D.R., \& Wang-Buhler, J.-L. (1998). Rainbow trout cytochrome P450s: purification,

643 molecular aspects, metabolic activity, induction and role in environmental monitoring.

644 Comparative Biochemistry and Physiology Part C, 121, 107-137.

645 Carls, M.G., Short, J.W., \& Payne, J. (2006). Accumulation of polycyclic aromatic hydrocarbons by Neocalanus copepods in Port Valdez, Alaska. Marine Pollution Bulletin,

Collier, T.K., \& Varanasi, U. (1992). Hepatic activities of xenobiotic metabolizing enzymes and biliary levels of xenobiotics in English Sole (Parophrys vetulus) exposed to environmental contaminants. Archives of Environmental Contamination and Toxicology, 20, 462-473.

Dickerson, R.L., Hooper, M.J., Gard, N.W., Cobb, G.P., \& Kendall, R.J. (1994). Toxicological foundations of ecological risk assessment: biomarker development and interpretation based on laboratory and wildlife species. Environmental Health Perspectives, 102, 65-69.

654 Echols, K.R., Gale, R.W., Schwartz, T.R., Huckins, J.N., Williams, L.L., Meadows, J.C., Morse, D., Petty, J.D., Orazio, C.E., \& Tillitt, D.E. (2000). Comparing polychlorinated biphenyl concentrations and patterns in the Saginaw River using sediment, caged fish, and semipermeable membrane devices. Environmental Science \& Technology, 34, 4095-4102.

658 Ewald, G., Larsson, P., Linge, H., Okla, L., \& Szarzi, N. (1998). Biotransport of organic pollutants to an inland Alaska lake by migrating sockeye salmon (Oncorhynchus nerka). Arctic, 51, 40-47. 
661

662

663

664

665

666

667

668

669

670

671

672

673

674

675

676

677

678

679

680

Flammarion, P., \& Garric, J. (1997). Cyprinids EROD activities in low contaminated rivers: a relevant statistical approach to estimate reference levels for EROD biomarker? Chemosphere, 35, 2375-2388.

Förlin, L., Andersson, T., Balk, L., Larsson, Å. (1995). Biochemical and physiological effects in fish exposed to bleached kraft mill effluents. Ecotoxicology and Environmental Safety, 30, 164-170.

Forbes, V.E., Palmqvist, A., \& Bach, L. (2006). The use and misuse of biomarkers in ecotoxicology. Environmental Toxicology and Chemistry, 25, 272-280.

Hodson, P.V., Efler, S., Wilson, J.Y., El-Shaarawi, A., Maj, M., \& Williams, T.G. (1996). Measuring the potency of pulp mill effluents for induction of hepatic mixed function oxygenase activity in fish. Journal of Toxicology and Environmental Health, 49, 83-110.

Huckins, J.N., Petty, J.D., Prest, H.F., Clark, R.C., Alvarez, D.A., Orazio, C.E., Lebo, J.A., Cranor, W.L., \& Johnson, B.T. (2000). A Guide for the Use of Semipermeable Membrane Devices (SPMDs) as Samplers of Waterborne Hydrophobic Contaminants. Columbia, MO, USA: Columbia Environmental Research Center, U.S. Geological Survey.

Huckins, J.N., Petty, J.D., \& Booij, K. (2006). Monitors of Organic Chemicals in the Environment: Semipermeable Membrane Devices. New York, NY, USA: Springer.

Huggett, R.J., Neff, J.M., Stegeman, J.J., Woodin, B., Parker, K.R., \& Brown, J.S. (2006). Biomarkers of PAH exposure in an intertidal fish species from Prince William Sound, Alaska: 2004-2005. Environmental Science \& Technology, 40, 6513-6517. 
681 Huggett, R.J., Stegeman, J.J., Page, D.S., Parker, K.R., \& Brown, J.S. (2003). Biomarkers in fish 682 from Prince William Sound and the Gulf of Alaska: 1999-2000. Environmental Science \& 683 Technology, 37, 4043-4051.

684 Huuskonen, S., Lindström-Seppä, P., Koponen, K., \& Roy, S. (1996). Effects of non-orthosubstituted polychlorinated biphenyls (congeners 77 and 126) on cytochrome P4501A and conjugation activities in rainbow trout (Oncorhynchus mykiss). Comparative Biochemistry and Physiology, 113C, 205-213.

Hyõtyläinen, T., \& Oikari, A. (1999). Assessment of the bioactivity of creosote-contaminated sediment by liver biotransformation system of rainbow trout. Ecotoxicology and Environmental Safety, 44, 253-258.

Jewett, S.C., Dean, T.A., Woodin, B.R., Hoberg, M.K., \& Stegeman, J.J. (2002). Exposure to hydrocarbons 10 years after the Exxon Valdez oil spill: evidence from cytochrome P4501A and biliary FACs in nearshore demersal fishes. Marine Environmental Research, 54, 21 48.

Kopponen, P., Tarhannen, J., Ruuskanen, J., Törrönen, R., \& Kärenlampi, S. (1993). Peat induces cytochrome P450IA1 in HEPA-1 cell line. Comparison with fly ashes from combustion of peat, coal, heavy fuel oil and hazardous waste. Chemosphere, 26, 14091506. 633-646. 
702

703

704

705

706

707

708

709

710

711

712

713

714

715

716

717

718

719

720

721

722

Krahn, M.M., Burrows, D.G., Ylitalo, G.M., Brown, D.W., Wigren, C.A., Collier, T.K., Chan, S.-L., \& Varanasi, U. (1992). Mass spectrometric analysis for aromatic compounds in bile of fish sampled after the Exxon Valdez oil spill. Environmental Science \& Technology, 26, 116-126.

Krümmel, E.M., Macdonald, R.W., Kimpe, L.E., Gregory-Eaves, I., Demers, M.J., Smol, J.P., Finney, B., \& Blais, J.M. (2003). Delivery of pollutants by spawning salmon. Nature, 425, 255-256.

Kvenvolden, K.A., Hostettler, F.D., Carlson, P.R., \& Rapp, J.B. (1995). Ubiquitous tar balls with a California-source signature on the shorelines of Prince William Sound, Alaska. Environmental Science \& Technology, 29, 2684-2694.

Lebo, J.A., Almeida, F.V., Cranor, W.L., Petty, J.D., Huckins, J.N., Rastall, A.C., Alvarez, D.A., Mogensen, B.B., \& Johnson, B.T. Purification of the triolein to be used in SPMDs. SETAC North America, November 12, 2003, at Austin, TX (USA). SETAC North America Abstracts 2003.

Lee, R.F., \& Anderson, J.W. (2005). Significance of cytochrome P450 system responses and levels of bile fluorescent aromatic compounds in marine wildlife following oil spills. Marine Pollution Bulletin, 50, 705-723.

Lemaire, P., Förlin, L., \& Livingstone, D.R. (1996). Responses of hepatic biotransformation and antioxidant enzymes to CYP1A-inducers (3-methylcholanthrene, $\beta$-naphthoflavone) in sea bass (Dicentrarchus labrax), dab (Limanda limanda), and rainbow trout (Oncorhynchus mykiss). Aquatic Toxicology, 36, 141-160. 
723 Lipiatou, E., \& Saliot, A. (1991). Fluxes and transport of anthropogenic and natural polycyclic 724 aromatic hydrocarbons in the western Mediterranean Sea. Marine Chemistry, 32, 51-71.

725 Lipiatou, E., \& Saliot, A. (1992). Biogenic aromatic hydrocarbon geochemistry in the Rhone 726 River delta and in surface sediments from the open North-Western Mediterranean Sea. 727 Estuarine, Gulf and Shelf Science, 34, 515-531.

728 Lohmann, R., Corrigan, B.P., Howsam, M., Jones, K.C., \& Ockenden, W.A. (2001). Further 729 developments in the use of semipermeable membrane devices (SPMDs) as passive air 730 samplers for persistent organic pollutants: field application in a spatial survey of PCDD/Fs and PAHs. Environmental Science \& Technology, 35, 2576-2582.

732 Matsuo, A.Y.O., Woodin, B.R., Reddy, C.M., Val, A.L., \& Stegeman, J.J. (2006). Humic substances and crude oil induce cytochrome P450 1A expression in the Amazonian fish species. Environmental Science \& Technology, 40, 2851-2858.

735 Meador, J.P., Stein, J.E., Reichert, W.L., \& Varanasi,U. (1995). Bioaccumulation of polycyclic aromatic hydrocarbons by marine organisms. In G. W. Ware (Ed.). Reviews of Environmental Contamination and Toxicology (pp.79-165). New York, NY, USA: Springer-Verlag,

739 Meadows, J.C., Echols, K.R., Huckins, J.N., Borsuk, F.A., Carline, R.F., \& Tillitt, D.E. (1998).

740 Estimation of uptake rate constants for PCB congeners accumulated by semipermeable 741 membrane devices and brown trout (Salmo trutta). Environmental Science \& Technology, $32,1847-1852$. 
743 Miles, M.S., Ashton, B.M., East, R., Bourke, S., Griswold, M., \& Overton, E.B. (2001).

744 Summary of chemistry results: shoreline monitoring study in Prince William Sound,

745 Alaska during the summer of 1999. IES/RCAT 01-01. Hazardous Materials Response and 746 Assessment Division, NOAA, Seattle, WA.

747 Neff, J.M., Bence, A.E., Parker, K.R., Page, D.S., Brown, J.S., \& Boehm, P.D. (2006). Bioavailability of polycyclic aromatic hydrocarbons from buried shoreline oil residues thirteen years after the Exxon Valdez oil spill: A multispecies assessment. Environmental

Neff, J.M., Boehm, P.D., Stubblefield, W.A., Kropp, R., \& Page, D.S. (2003). Monitoring recovery of Prince William Sound, Alaska, following the Exxon Valdez oil spill: bioavailability of PAH in offshore sediments. In Proceedings of the International Oil Spill Toxicology and Chemistry, 25, 947-961.

Niimi, A.J., \& Palazzo, V. (1986). Biological half-lives of eight polycyclic aromatic hydrocarbons (PAHs) in rainbow trout (Salmo gairdneri). Water Research, 20, 503-507.

Niimi, A.J., \& Dookhran, G.P. (1989). Dietary absorption efficiencies and elimination rates of polycyclic aromatic hydrocarbons (PAHs) in rainbow trout (Salmo gairdneri). Environmental Toxicology and Chemistry, 8, 719-722.

NRC: Committee on Biological Markers of the National Research Council. (1987). Biological markers in environmental health research. Environmental Health Perspectives, 74, 3-9.

762 Ockenden, W.A., Sweetman, A.J., Prest, H.F., Steinnes, E., Jones, K.C. (1998). Toward an understanding of the global atmospheric distribution of persistent organic pollutants: the 
use of semipermeable membrane devices as time-integrated passive samplers. Environmental Science \& Technology, 32, 2795-2803.

766

Page, D.S., Boehm, P.D., Douglas, G.S., Bence, A.E., Burns, W.A., \& Mankiewicz, P.J. (1999). Pyrogenic polycyclic aromatic hydrocarbons in sediments record past human activity: a case study in Prince William Sound, Alaska. Marine Pollution Bulletin, 38, 247-260.

Page, D.S., Boehm, P.D., Douglas, G.S., Bence, A.E., \& Mankiewicz, P.J., (1996). The natural petroleum hydrocarbon background in subtidal sediments of Prince William Sound, Alaska, USA. Environmental Toxicology and Chemistry, 15, 1266-1281.

Page, D.S., Huggett, R.J., Stegeman, J.J., Parker, K.R., Woodin, B., Brown, J.S., \& Bence, A.E. (2004). Polycyclic aromatic hydrocarbon sources related to biomarker levels in fish from Prince William Sound and the Gulf of Alaska. Environmental Science \& Technology, 38, 4928-4936.

Page, D.S., Brown, J.S., Boehm, P.D., Bence, A.E., \& Neff, J.M. (2006). A hierarchical approach measures the aerial extent and concentration levels of PAH-contaminated shoreline sediments at historic industrial sites in Prince William Sound, Alaska. Marine Pollution Bulletin, 52, 367-379.

Parrott, J.L., Backus, S.M., Borgmann, A.I., \& Swyripa, M. (1999). The use of semipermeable membrane devices to concentrate chemicals in oil refinery effluent on the Mackenzie River. Arctic, 52, 125-138. 
783 Pohl, R.J., \& Fouts, J.R. (1980). A rapid method for assaying the metabolism of 7-

784 ethoxyresorufin by microsomal subcellular fractions. Analytical Biochemistry, 107, 150-

$785 \quad 155$.

786 Sabaliûnas, D., Ellington, J., \& Sabliûnienë, I. (1999). Screening bioavailable hydrophobic

787 toxicants in surface waters with semipermeable membrane devices: role of inherent oleic

788 acid in toxicity evaluations. Ecotoxicology and Environmental Safety, 44, 160-167.

789 Schmidt, G.M. (1977). The exchange of water between Prince William Sound and the Gulf of

$790 \quad$ Alaska. MSc thesis, University of Alaska, Fairbanks, AK

791 Schwartz, R.M. (2006). Comparison of mussels and semi-permeable membrane devices as inter-

792 tidal monitors of polycyclic aromatic hydrocarbons at oil spill sites (Boehm et al., 2005).

793 Marine Pollution Bulletin, 52, 121.

794 Short, J.W., \& Babcock, M.M. (1996). Prespill and postspill concentrations of hydrocarbons in

795 mussels and sediments in Prince William Sound. In S. D. Rice, R. B. Spies, D. A. Wolfe \&

796 B. A. Wright (Eds.). Proceedings of the Exxon Valdez Oil Spill Symposium. American

797 Fisheries Society Symposium 18, Bethesda, Maryland, 149-166.

798 Short, J.W., Irvine, G.V., Mann, D.H., Maselko, J.M., Pella, J.J., Lindeberg, M.R., Payne, J.R.,

799 Driskell, W.B., \& Rice, S.D. (2007). Slightly weathered Exxon Valdez oil persists on Gulf

$800 \quad$ of Alaska beach sediments after 16 years. Environmental Science \& Technology, 41, 1245-

$801 \quad 1250$. 
802

803

804

805

806

807

808

809

810

811

812

813

814

815

816

817

818

819

820

821

Short, J.W., Kvenvolden, K.A., Carlson, P.R., Hostettler, F.D., Rosenbauer, R.J., \& Wright, B.A. (1999). Natural hydrocarbon background in benthic sediments of Prince William Sound, Alaska: oil vs. coal. Environmental Science \& Technology, 33, 34-42.

Short, J.W., Lindeberg, M.R., Harris, P.M., Maselko, J.M., Pella, J.J., \& Rice, S.D. (2004). Estimate of oil persisting on the beaches of Prince William Sound 12 years after the Exxon Valdez oil spill. Environmental Science \& Technology, 38, 1564-1572.

Short, J.W., Maselko, J.M., Lindeberg, M.R., Harris, P.M., \& Rice, S.D. (2006). Vertical distribution and probability of encountering intertidal Exxon Valdez oil on shorelines of three embayments within Prince William Sound, Alaska. Environmental Science \& Technology, 40, 3723-3729.

Short, J.W., \& Springman, K.R. (2006). Identification of hydrocarbons in biological samples for source determination. In: Z. Wang and S. A. Stout (Eds.). Oil Spill Environmental Forensics - Fingerprinting and Source Identification. London: Elsevier Science.

Short, J.W., Springman, K.R., Lindeberg, M.R., Holland, L.G., Larsen, M.L., Sloan, C.A., Khan, C., Hodson, P.V., \& Rice, S.D. (2008). Semipermeable membrane devices link sitespecific contaminants to effects: Part II - a comparison of lingering Exxon Valdez oil with other potential sources of CYP1A inducers in Prince William Sound, Alaska. Marine Environmental Research (submitted).

Springman, K.R., Kurath, G., Anderson, J.J., \& Emlen, J.M. (2005). Contaminants as viral cofactors: assessing indirect population effects. Aquatic Toxicology, 71, 13-23. 
822 Stegeman, J.J., \& Hahn, M.E. (1994). Biochemistry and molecular biology of monooxygenases:

823 current perspectives on forms, functions, and regulation of cytochrome $\mathrm{P} 450$ in aquatic

824 species. In: D. C. Malins and G. K. Ostrander (Eds.). Aquatic Toxicology: Molecular,

825 Biochemical and Cellular Perspectives. Lewis Publishers, Boca Raton, Florida, pp. 87-206.

826 Stern, G.A., Halsall, C.J., Barrie, L.A., Muir, D.C.G., Fellin, P., Rosenberg, B., Rovinsky, F.Y.,

827 Kononov, E.Y., \& Pastuhov, B. (1997). Polychlorinated biphenyls in Arctic air .1.

828 Temporal and spatial trends: 1992-1994. Environmental Science \& Technology, 31, 3619-

8293628.

830 Sundberg, H., Tjärnlund, U., Åkerman, G., Blomberg, M., Ishaq, R., Grunder, K., Hammar, T.,

831 Broman, D., \& Balk, L. (2005). The distribution and relative toxic potential of organic

832 chemicals in a PCB contaminated bay. Marine Pollution Bulletin, 50, 195-207.

833 Trust, K.A., Esler, D., Woodin, B.R., \& Stegeman, J.J. (2000). Cytochrome P450 1A induction

834 in sea ducks inhabiting nearshore areas of Prince William Sound, Alaska. Marine

$835 \quad$ Pollution Bulletin, 40, 397-403.

836 U.S. EPA. (1986). Laboratory Manual Physical/Chemical Methods, SW 846. Washington, D.C.:

837 U.S. EPA.

838 Villeneuve, D.L., Crunkilton, R.L., \& DeVita, W.M. (1997). Aryl hydrocarbon receptor-

839 mediated toxic potency of dissolved lipophilic organic contaminants collected from

840 Lincoln Creek, Milwaukee, Wisconsin, USA, to PLHC-1 (Poeciliopsis lucida) fish

841 hepatoma cells. Environmental Toxicology and Chemistry, 16, 977-984. 
842 Whyte, J.J., Jung, R.E., Schmitt, C.J., \& Tillitt, D.E. (2000). Ethoxyresorufin-o-deethylase

843 (EROD) activity in fish as a biomarker of chemical exposure. Critical Reviews in

844 Toxicology, 30, 347-570.

845 Woodin, B.R., Smolowitz, R.M., \& Stegeman, J.J. (1997). Induction of cytochrome P4501A in

846 the intertidal fish Anoplarchus purpurescens by Prudhoe Bay crude oil and environmental

847 induction in fish from Prince William Sound. Environmental Science \& Technology, 31,

$848 \quad 1198-1205$.

849 Wooley, C. (2002). The myth of the "pristine environment": past human impacts in Prince

850 William Sound and the northern Gulf of Alaska. Spill Science \& Technology Bulletin, 7,

$851 \quad 89-104$. 


\section{Figure Legends}

855 Figure 1. Location of SPMD deployment sites in Prince William Sound, Alaska.

856 Figure 2. EROD response to SPMD extracts from the oiled ANS sites used in this study. Sites

857 KN114A1, KN114A2, KN136A and KN109A are located on Knight Island; EL56C1, EL56C2

858 and EL56C3 are sites on Eleanor Island; DI67A1 and DI67A2 are on Disk Island (See Short et

859 al., 2008 for a detailed map). The field blank (FB), field control (FC) and positive control ( $\beta$ -

860 naphthoflavone; BNF) responses are included for comparison. Mean EROD activities are derived

861 from the logarithmic mean of $(n)$ individuals, with \pm 1 SE. White bars indicate $2 \mathrm{~d}$ response and

862 grey bars are $7 \mathrm{~d}$. No data are available where noted.

863

864 Figure 3. EROD response to SPMD extracts from the human activity and salmon hatchery sites

865 (as noted) including Armin F. Koernig (AFK) hatchery. White bars indicate $2 \mathrm{~d}$ response and

866 grey bars are $7 \mathrm{~d}$. Asterisks indicate significant increases $(t$-test $P<0.05)$.

868 Figure 4. EROD responses to SPMD extracts from salmon streams (SS) and random sites (RS)

869 in both fall and spring. Responses from the peanut oil injections (PNUT) are included for

870 comparison. White bars indicate $2 \mathrm{~d}$ response, grey bars are $7 \mathrm{~d}$. Asterisks indicate significant

871 increases compared to PNUT $(P<0.036)$.

872 


\section{ACCEPTED MANUSCRIPT}

873

874

875

876

877

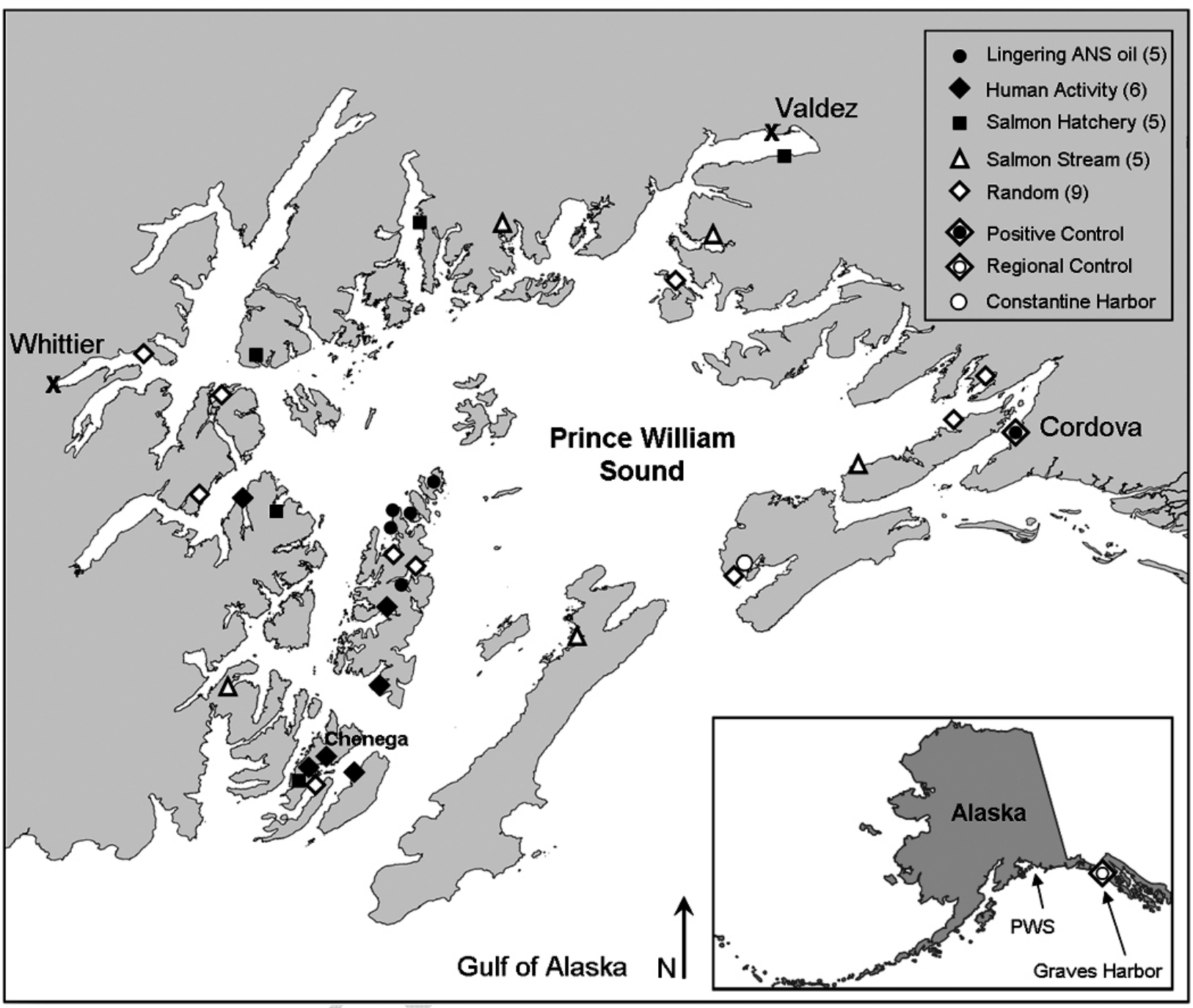

Figure 1. Location of SPMD deployment sites in Prince William Sound, Alaska. 


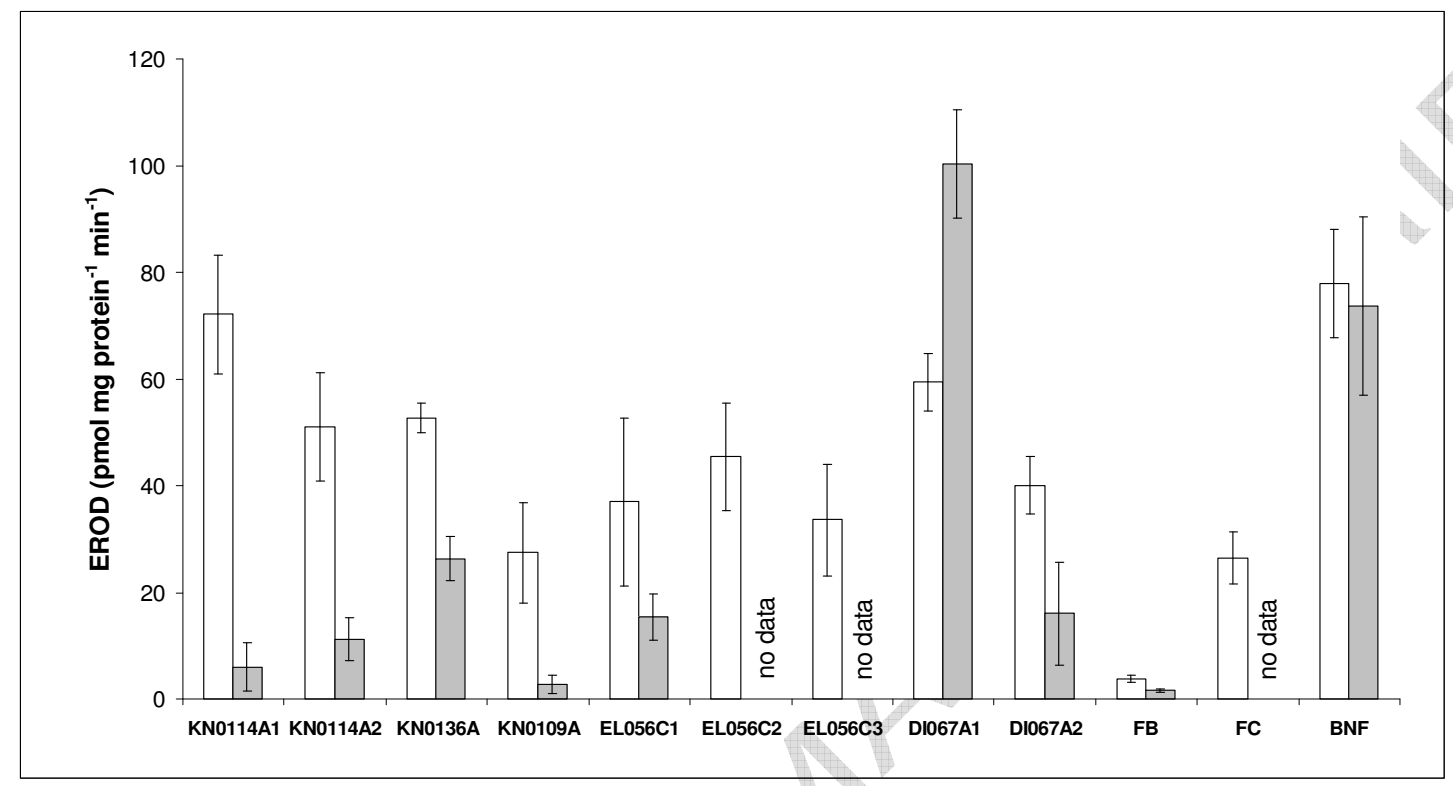

878

879 Figure 2. EROD response to SPMD extracts from the oiled ANS sites used in this study. Sites

880 KN114A1, KN114A2, KN136A and KN109A are located on Knight Island; EL56C1, EL56C2

881 and EL56C3 are sites on Eleanor Island; DI67A1 and DI67A2 are on Disk Island (See Short et

882 al., 2008 for a detailed map). The field blank (FB), field control (FC) and positive control ( $\beta$ -

883 naphthoflavone; BNF) responses are included for comparison. Mean EROD activities are derived

884 from the logarithmic mean of $(n)$ individuals, with \pm 1 SE. White bars indicate $2 \mathrm{~d}$ response and

885 grey bars are $7 \mathrm{~d}$. No data are available where noted. 


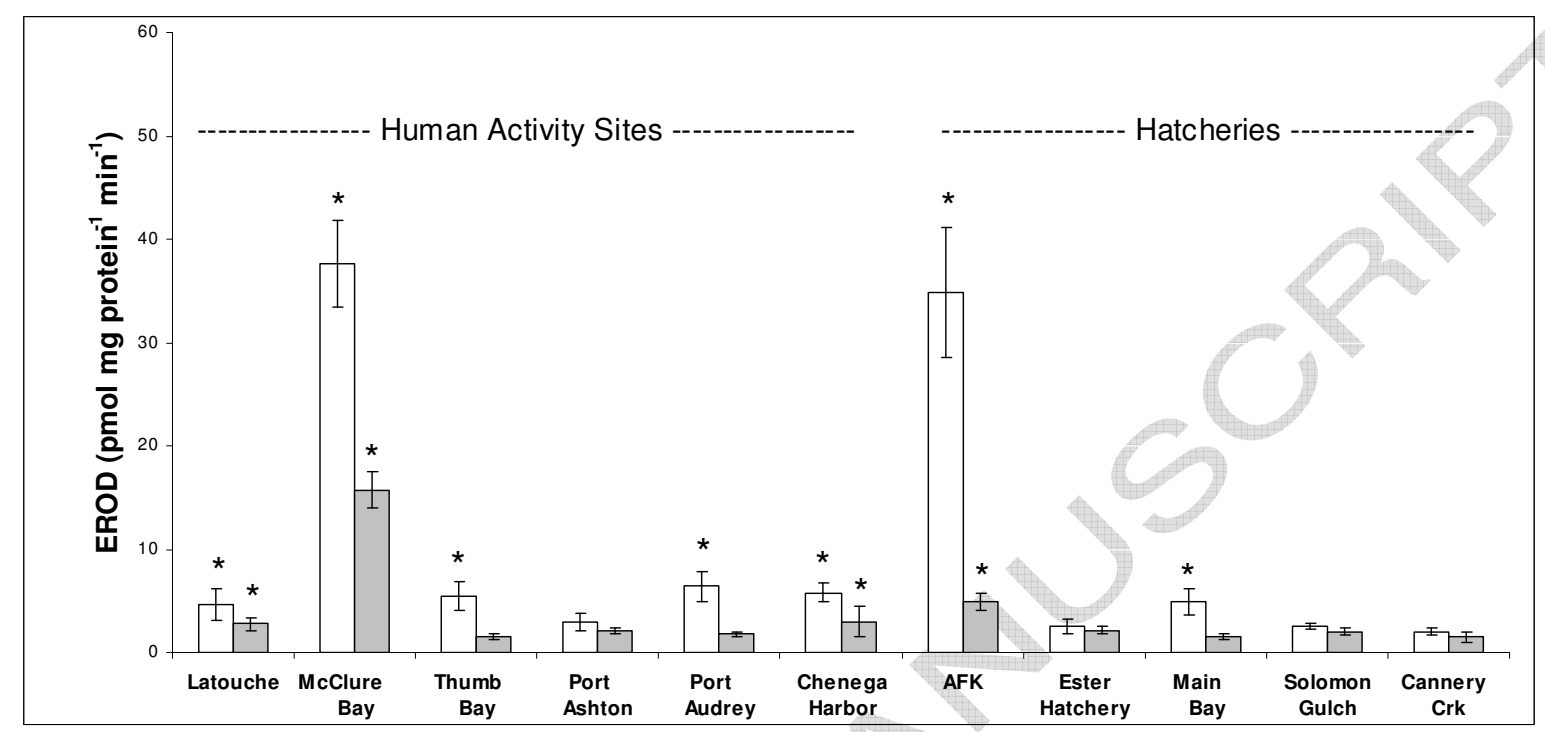

888 Figure 3. EROD response to SPMD extracts from the human activity and salmon hatchery sites

889 (as noted) including Armin F. Koernig (AFK) hatchery. White bars indicate $2 \mathrm{~d}$ response and

890 grey bars are $7 \mathrm{~d}$. Asterisks indicate significant increases $(t$-test $P<0.05)$. 


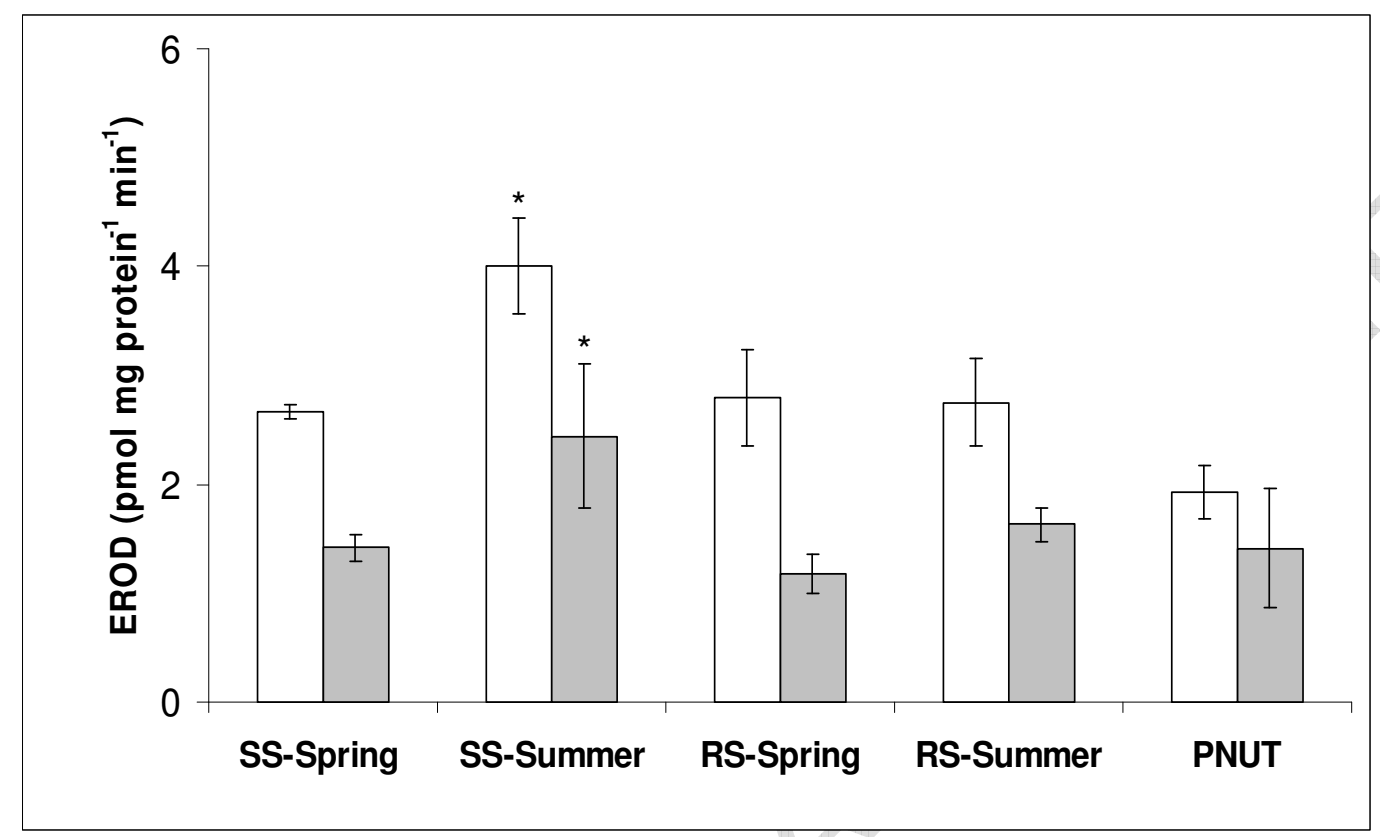

896 Figure 4. EROD responses to SPMD extracts from salmon streams (SS) and random sites (RS)

897 in both fall and spring. Responses from the peanut oil injections (PNUT) are included for

898 comparison. White bars indicate $2 \mathrm{~d}$ response, grey bars are $7 \mathrm{~d}$. Asterisks indicate significant

899 increases compared to PNUT $(P<0.036)$.

900 
901 Table 1. Basal EROD activity of juvenile rainbow trout (denoted "not injected") compared with

902 EROD responses to negative and positive control treatments and responses from SPMD

903 deployments at un-contaminated sites. Mean EROD activities are given as $\mathrm{pmol} \mathrm{mg}^{-1} \mathrm{~min}^{-1}$,

904 derived from the logarithmic mean of $(n)$ individuals, with \pm 1 SE in parentheses below.

905

$\underline{\text { Site/Treatment Category }}$

Not Injected

Peanut Oil

Field Blanks

Un-Contaminated Sites

BNF

Cordova Harbor

\section{EROD Activity}

$0.932(5)$

$(0.849-1.02)$

2-Day

7-Day

$1.87(5)$

$1.13(5)$

$(1.66-2.10)$

$(0.835-1.53)$

3.78 (22)

$2.45(20)$

$(3.41-4.21)$

$(2.07-2.90)$

$2.24(80)$

$1.19(78)$

$(2.10-2.38)$

(1.11-1.27)

$75.3(4)$

$65.8(5)$

$(64.6-87.7)$

$(51.5-84.0)$

40.3 (10) $(34.9-46.5)$

no data 